\title{
Effectiveness of dental records in human identification
}

\author{
Efetividade da documentação odontológica na identificação humana
}

\author{
Salen Marchesi de ALMEIDA ${ }^{1}$ \\ Fábio DELWING ${ }^{1}$ \\ Juliana Aires Paiva de AZEVEDO' \\ Renata Kelly Trajano NOGUEIRA' \\ Flávio Pinheiro FALCÃO ${ }^{1}$ \\ Suzana Papile Maciel CARVALHO²
}

\begin{abstract}
Forensic dentistry, a branch of the forensic sciences, plays an important role within postmortem human identification, especially in cases of corpses that are charred, skeletonized or in an advanced state of decomposition. Identification of human remains via dental knowledge is done using a comparative technique, which is simple, inexpensive and reliable, the aim of which is to compare dental records and information recorded by dentists in clinical appointments made before an individual's death, with postmortem dental records obtained via forensic examination. In this context, the present study aims to demonstrate the importance of dental records and the effectiveness of forensic dentistry in human identification, illustrated by the report of a case that was conducted at the São Luis Coroner's Office in the Brazilian state of Maranhão. It may be concluded that dental records maintained by a dentist, when complete, properly structured and correctly archived, retain important personal information and are fundamental tools in the process of human identification.
\end{abstract}

Indexing terms: Dental records. Forensic dentistry. Forensic anthropology.

\section{RESUMO}

A Odontologia Legal, ramo das Ciências Forenses, tem importante atuação nas perícias de identificação humana post-mortem, sobretudo na ocorrência de cadáveres em avançado estado de putrefação, carbonizados e esqueletizados. O processo odontológico de identificação humana é realizado por meio de técnica comparativa, o qual é simples, de baixo custo e confiável, que busca relacionar as informações e características odontológicas, registradas em prontuário clínico, antes da morte de um indivíduo, com as particularidades odontológicas encontradas no exame pericial após a morte. Neste contexto, o presente trabalho teve como objetivo demonstrar a importância da documentação odontológica e a efetividade da odontologia legal no processo de identificação humana, por meio de um relato de caso do Instituto Médico Legal de São Luís, Maranhão, Brasil. Pode-se concluir que o prontuário odontológico, elaborado pelo cirurgião-dentista na clínica diária, quando bem estruturado, completo e arquivado corretamente, armazena informações pessoais importantes, sendo ferramenta fundamental no processo de identificação humana.

Termos de indexação: Documentação. Identificação humana. Odontologia legal.

\section{INTRODUCTION}

Forensic dentistry is a challenging branch of forensic science, which combines dentistry and law and is based on the application of dental knowledge in order to provide assistance to the justice system ${ }^{1-3}$.

Within the scope of forensic dentistry is its use in criminal law, encompassing the examination of whole or fragmented corpses in order to identify them. This is done by dental surgeons who are forensic experts for the Coroner's Office ${ }^{3}$.

Identification is the process by which an individual's identity is determined, defining individuality and establishing characteristics and peculiarities that differentiate one individual from another ${ }^{3}$. This endeavor is indispensable on account of the ethical, legal and civil reasons involved. Every family has the right to bury a deceased family member. At the same time, without identification of the corpse, many civil proceedings cannot

\footnotetext{
${ }^{1}$ Instituto Médico Legal de São Luís, Seção de Odontologia Legal. Av. dos Portugueses, 3779, Vila Bacanga, 65085-582, São Luís, MA, Brasil. Correspondência para / Correspondence to: SM ALMEIDA. E-mail: <salenmarchesi@hotmail.com>

${ }^{2}$ Universidade de São Paulo, Faculdade de Odontologia, Departamento de Odontologia Legal. Bauru, SP, Brasil.
} 
be concluded, cases regarding inheritance and insurance payments being good examples. Moreover, without being able to identify the victim, a crime may be practically unsolvable ${ }^{4}$.

The most common means of determining an individual's identity used by the Coroner's Office are visual recognition (considered to be an empirical identification, subjective and lacking in scientific cogency ${ }^{5}$ ), fingerprint analysis, forensic dentistry and DNA analysis (the last three being characterized by the use of scientific techniques). It is worth noting that there is no hierarchy among these techniques; the methodology of choice in each case depends on the body's condition ${ }^{6-7}$.

In situations where visual recognition and other identification methods, such as fingerprint analysis, tend to be less efficient, safe or even viable (as is the case of bodies that are charred, skeletonized or in and advanced stage of decomposition), forensic dentistry comes to the fore, as the teeth are the most resistant structures of the human body and are frequently found to be well preserved after death, even when caused by fire or water ${ }^{8-9}$. Furthermore, studies show that the materials used in dental restorations are highly durable and resistant, remaining in the dental cavity even when subjected to high temperatures ${ }^{10}$, thereby aiding the identification process.

As for DNA testing, although this is possible in many situations and produces highly reliable results, it has some disadvantages, such as high operational costs and the technology necessary for performing the technique ${ }^{11-13}$.

Human identification using dental methodology is based on the fact that no two individuals have the same dental composition, not even identical twins, who share the same $D_{N A}{ }^{14}$. The methodology is simple, inexpensive and quick, yet accurate and reliable. It is classified as a comparative methodology, as antemortem and postmortem data are compared, due to the set of dental characteristics being individual and inherent to each person ${ }^{15}$.

Meanwhile, forensic dental tests for the purposes of identification are divided into three stages, the first of which is identifying a corpse's dental particularities. The second stage is the collection and observation of the information and characteristics contained in a supposed victim's antemortem dental records. The third stage involves a comparison of the data obtained in order to conduct a thorough verification of their similarities and differences, both quantitatively and qualitatively ${ }^{16}$.

Complete dental records, maintained by clinics, are a basic prerequisite for the tests to take place. Obtaining satisfactory results is directly linked to the quantity and quality of the information contained in these records. Conversely, flaws in these records may lead to the loss of relevant data, making identification difficult or even impossible ${ }^{17-18}$.

In cases where dental records are not available, forensic dentistry seeks to create a profile that indicates the individual's oral habits, diet and probable age. It may even be possible to determine the individual's socioeconomic status $^{19}$.

In this context, the present study aims to report on a case of identification of a body at an advanced stage of decomposition using forensic dentistry and thereby highlight the importance of dental records.

\section{CASE REPORT}

In 2014, a corpse was found in the sea off São Luis, in the Brazilian state of Maranhão, and was delivered to the Coroner's Office to undergo forensic tests in order to determine the cause of death, the instrument or means that caused the death and the victim's identity. Visual recognition was not possible as the corpse was in an advanced stage of decomposition and was partly skeletonized. There was soft tissue in the cranial region, black hair partially dyed red and an absence of upper limbs, which made the use of fingerprint analysis to identify the corpse impossible. Forensic dentistry was the methodology of choice for identification, as the dental arches were intact.

To examine the corpse's teeth, a bilateral incision was made from the labial commissure to the zygomatic arch aexposing the dental arches. Forensic dental analysis of the corpse showed several characteristics of forensic importance, such as amalgam fillings, extractions and bad tooth position.

Relatives of the missing young woman, who had last been seen at the beach, claimed the body at the Coroner's Office. They were then asked to provide any dental records they had, as well as current photographs of the woman smiling. They provided a photograph of the supposed victim and her dental records from 2006, which revealed that some dental procedures had been performed (Figure 1). The relatives then answered a questionnaire and stated that the supposed victim had black hair, partially dyed red, and had upper anterior crowding.

The particularities found in the antemortem (AM) and postmortem (PM) examinations can be seen more clearly in the table below (Table 1). 


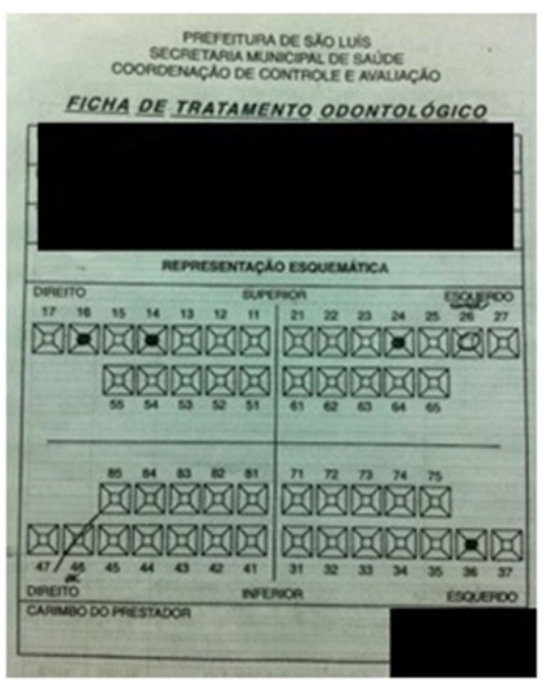

Figure 1. Dental records of the supposed victim

Table 1. Forensic dental comparison of antemortem (AM) and postmortem (PM) information.

\begin{tabular}{|c|c|c|}
\hline Tooth & $\begin{array}{l}\text { antemortem (AM) } \\
\text { information }\end{array}$ & $\begin{array}{l}\text { postmortem (PM) } \\
\text { information }\end{array}$ \\
\hline 16 & $\begin{array}{c}\text { Amalgam filling on occlusal } \\
\text { surface }\end{array}$ & $\begin{array}{l}\text { Amalgam filling on occlusal } \\
\text { surface }\end{array}$ \\
\hline 14 & $\begin{array}{c}\text { Amalgam filling on occlusal } \\
\text { surface }\end{array}$ & $\begin{array}{c}\text { Amalgam filling on occlusal } \\
\text { surface }\end{array}$ \\
\hline 13 & Proclined & Proclined \\
\hline 12 & $\begin{array}{c}\text { In contrast to teeth \#13 and } \\
\# 11, \text { turning in towards } \\
\text { palate }\end{array}$ & $\begin{array}{l}\text { In contrast to teeth \#13 } \\
\text { and \#11, turning in } \\
\text { towards palate }\end{array}$ \\
\hline 24 & $\begin{array}{l}\text { Amalgam filling on occlusal } \\
\text { surface }\end{array}$ & $\begin{array}{l}\text { Amalgam filling on occlusal } \\
\text { surface }\end{array}$ \\
\hline 26 & $\begin{array}{l}\text { Indicated for endodontic } \\
\text { treatment }\end{array}$ & Reduced to root fragments \\
\hline 36 & $\begin{array}{l}\text { Amalgam filling on occlusal } \\
\text { surface }\end{array}$ & $\begin{array}{c}\text { Amalgam filling on occlusal } \\
\text { surface }\end{array}$ \\
\hline 46 & Extracted & $\begin{array}{c}\text { Missing, with remodeled } \\
\text { bone ridge }\end{array}$ \\
\hline
\end{tabular}

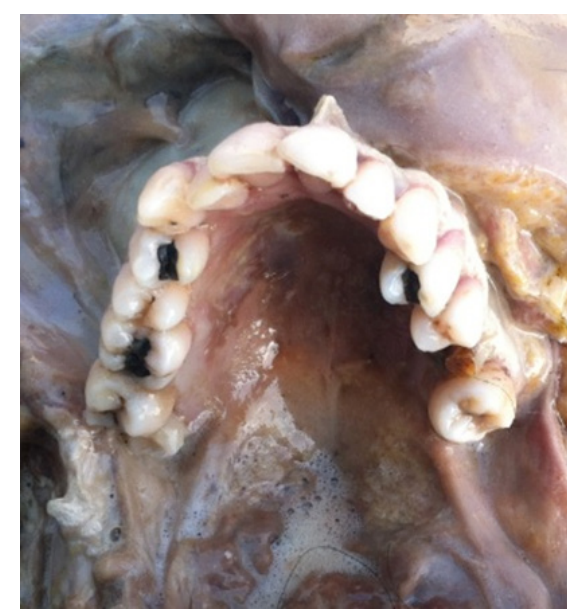

Figure 2. The corpse's maxilla

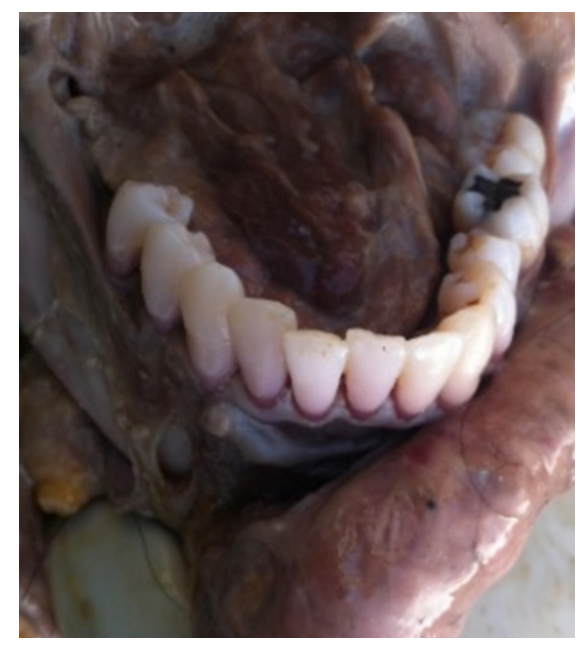

Figure 3. The corpse's mandible

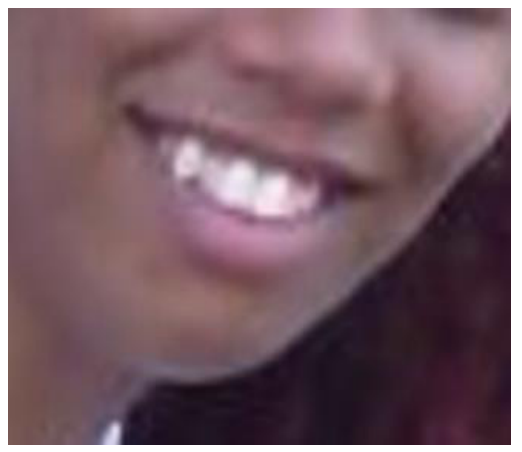

Figure 4. Antemortem photograph.

\section{DISCUSSION}

Forensic dentistry contributes to the process of human identification via detailed studies of individual dental characteristics. To this end, the availability of a victim's dental records is necessary. The fundamental aim of these records is primarily clinical, however, in some situations, they have significant legal value, contributing to legal issues such as forensic identification ${ }^{15}$.

In the present case, teeth \#16 (maxillary right first molar), \#14 (maxillary right first pre-molar), \#24 (maxillary left first pre-molar) and \#36 (mandibular left first molar), which on the dental records were shown to have amalgam fillings on their occlusal surfaces, corresponded with the findings of the autopsy (Figure 2). It is important to note that the dental surgeon identified the material used in the fillings and sketched the surface of the affected teeth on the odontogram.

Tooth \#26 (maxillary left first molar) was found to be reduced to root fragments. In the dental records, 
this tooth had been indicated for endodontic treatment in 2006. Thus, eight years having passed, it is consistent that the tooth would be reduced to root fragments as a result of not having received the indicated treatment and care. Tooth \#46 (mandibular right first molar) was not present in the corpse's dental arch, consistent with the antemortem dental records, in which its extraction is shown (figure 3).

Tooth \#13 (maxillary right canine) of the corpse exhibited proclination and tooth \#12 (maxillary right lateral incisor) was turned in towards the palate, in contrast to tooth \#13 (maxillary right canine) and tooth \#11 (maxillary right central incisor). These characteristics were also evidenced in the smile in the photograph provided by the family of the supposed victim (figure 4). It was also possible to analyze the anatomical appearance of the crowns of the maxillary central incisors.

The use of smile photographs in the process of human identification is widely accepted as they can provide accurate, useful information as to the anatomical and positional characteristics of teeth ${ }^{19-20}$.

As also stated by the relatives, it can be proved, using the photographs provided, that the hair of the supposed victim was partially dyed red, which is consistent with the findings of the autopsy. The compatibility of the hair found on the corpse was not sufficient nor exclusive enough to confirm its identity, but was useful as a piece of ancillary data for the examination ${ }^{17}$.

Some of the postmortem findings, for example the clinical absence of tooth \#47 (mandibular right second molar), cannot be challenged given the dental records provided. However, this fact may be explained by the time that elapsed between the date of the dental record and the date the examination was performed and was not, therefore, considered to be incompatible with the identification in the examination.

The comparison of dental data, besides the several consistencies found, showed several important qualitative characteristics and no discrepancies, resulting in positive identification of the victim. Thus, the importance of clinical

\section{REFERENCES}

1. Silva RF, Pereira SDR, Mendes SDSC, Marinho DEA, Daruge Júnior E. Radiografias odontológicas: fonte de informação para a identificação humana. Odontol Clín Científ. 2006;5(3):23942.

2. Wadhwan V, Shetty DC, Jain A, Khanna KS, Gupta A. A call for a new speciality: Forensic odontology as a subject. J Forensic Dent Sci. 2014;6(2):97-100. doi: 10.4103/0975-1475.132535 records as pillars of the process of human identification should be stressed.

It should be noted that it is not possible to establish a minimum number of consistencies to determine positive forensic dental identification, as the study deals with both quantitative and qualitative elements ${ }^{7}$.

\section{CONCLUSION}

Forensic dentistry is an efficient and safe method of human identification. However, the availability of antemortem dental records for comparison is required in order to ensure success. In the case study shown, the clear and correct clinical recording of the dental procedures performed, including information on the material used in fillings and the affected dental surfaces as well as records of the extraction performed, among other factors, facilitated and enabled identification of the victim. In cases where there are incorrect records, which use acronyms or abbreviations that are difficult to understand, do not specify the materials used and dental surfaces affected, omit procedures performed or describe procedures that have not been performed when they have, the identification process would be impaired or even rendered unviable. Therefore, dental professionals working in clinics have an important role to play in the identification process, contributing directly via the production of dental records that are in compliance with recommended ethical and legal parameters.

\section{Collaborators}

SM ALMEIDA took part in the design, outline, preparation, research and composition of the article. $F$ DELWING, JAP AZEVEDO, RKT NOGUEIRA and FP FALCÃO took part in the revision, research and composition of the article. SPM CARVALHO directed the research and took part in the outline, preparation, research, revision and composition of the article.

3. Vanrell JP. Odontologia legal e antropologia forense. 2a ed. Rio de Janeiro: Guanabara Koogan; 2009

4. Cattaneo C, Porta D, De Angelis D, Gibelli D, Poppa P, Grandi M. Unidentified bodies and human remains: an Italian glimpse through a European problem. Forensic Sci Int. 2010;195 (13):167. doi: 10.1016/j.forsciint.2009.11.008

5. Oliveira RN, Daruge E, Galvão LCC, Tumang AJ. Contribuição da odontologia legal à identificação post-mortem. Rev Bras Odontol. 1998;55(2):117-22 
6. Silva RF, Portilho CDM, Reges RV, Leles CR, Freitas GC, Daruge Júnior E. Importância pericial dos registros odontológicos decorrentes de tratamento restaurador. Rev Dent Press Estét. 2007;4(4):32-8.

7. Silva RF, Prado MM, Oliveira HCM, Daruge Júnior E. Quantos pontos de concordância são necessários para se obter uma identificação odontolegal positiva? Rev Odontol Univ Cid São Paulo. 2009;21(1):63.

8. Silveira EMSZSF. A importância do odontolegista dentro do Instituto Médico Legal. Rev Bras Med Trab. 2013;11(1):34-9.

9. Menon LML, Prado KFB, Silva RHA. Avaliação histológica da dentina e do cemento após diferentes tempos de imunação: estudo in vitro. RSBO Rev Sul Bras. 2011;8(2):131-7.

10. Spadácio C, Oliveira OF, Benedicto EN, Daruge Júnior E, Paranhos LR. Análise do comportamento de restaurações estéticas sob a ação de calor e sua importância no processo de identificação humana. RFO UFP. 2011;16(3):267-72.

11. Silva RF, Pereira SDR, Mendes SDSC, Marinho DEA, Daruge Júnior E. Radiografias Odontológicas: Fonte de informação para a identificação humana. Odontol Clín Científ. 2006;5(3):23942.

12. Silva RF, Pereira SDR, Daruge Júnior E, Daruge E, Francesquini Júnior L. A confiabilidade do exame odontolegal na identificação humana. ROBRAC. 2004;13(35):46-50.

13. Coutinho CGV, Ferreira CA, Queiroz LR, Gomes LO, Silva UA O papel do odontolegista nas perícias criminais. RFO UFP. 2013:18(2):217-23.
14. Espindula A Geiser GC, Velho JA. Ciências forenses: uma introdução às principais áreas da criminalística moderna. 2a ed. Campinas: Millennium; 2013.

15. Silva RF, Benta NG, Daruge Júnior E, Prado MM, Melo M. Importância pericial dos registros odontológicos decorrentes de tratamento protético. Rev Odonto. 2008 jul-dez;16(32):137-143. doi: 10.15603/2176-1000/

16. Silva RF, Prado MM, Barbieri AA, Daruge Júnior E. Utilização de registros odontológicos para identificação humana. RSBO. 2009;6(1):95-9.

17. Tsuchiya MJ, Gomes EM, Abe DM, Oliveira FVN, Massaoka C, Oliveira RN. Human identification through the analysis of dental records registered in the context of a Dental Institution. RGO Rev Gaúch Odontol. 2013 jul-set;61(3):389-93.

18. Paranhos LR, Caldas JCF, Iwashita AR, Scanavini MA, Paschini RC. A importância do prontuário odontológico nas perícias de identificação humana. RFO UPF. 2009 jan-abr;14(1):14-7.

19. Al-Ahmad SH. Forensic Odontology. Smile Dent J. 2009;4:22-4.

20. Silva RF, Pereira SD, Prado FB, Daruge Júnior E, Daruge E. Forensic Odontology identification using smile photograph analysis - case reports. J Forensic Odontostomatol. 2008 Jun;26(1):12-17.

Received on: 24/6/2015

Final version resubmitted on: 3/8/2015

Approved on: 31/8/2015 